\title{
Literature Study Description of Corporation Between Classroom Teacher and School Counselor In Elementary School
}

\author{
Ririanti Rachmayanie \\ Departement of Guidance and Counseling \\ Lambung Mangkurat University \\ Banjarmasin, Indonesia \\ ririanti.bk@ulm.ac.id
}

\begin{abstract}
The purpose of the literature review of this article is to reveal the cooperative relationship between the guidance teacher and the school counselor. The literature review method undertaken is to collect a number of studies on the implementation of guidance and counseling in elementary schools from 2014 to 2017, the result collected seven relevant studies were obtained on the topic of the study. The findings of data analysis with comparative data of the study revealed that there are three important points of relationship of guidance teacher with school counselor that is in implementing guidance and counseling service, helping by giving opportunity for student to follow guidance and counseling service, and lastly provide information to students who need special attention when the service is given.
\end{abstract}

Keywords-School counseling; counselor; guidance teacher

\section{INTRODUCTION}

The existence of elementary school counseling and counseling in Indonesia is relatively new, although the idea has long since echoed since its counseling and existence counseling is widely known. Whereas the great role of guidance and counseling is not less important to help elementary school students, in this case[1], suggests that school counselors at the elementary school level, have a major contribution in developing positive life of elementary school students. In addition, they are required to build perspectives as teachers who are able to work in partnership with other teachers (classroom teacher) to create qualified education that focuses on preparing students to accept themselves as early as possible as part of the dynamics of community life. In order to carry out its primary role, a school counselor at the level of basic education is required to play a role as a leader, manager, social agent of change and provider of guidance service procedures and counseling process procedures. On the other hand, a school counselor can't be separated from the fact of everyday practice that demands them to be always ready and available. It is also important for them to reach the success of the elementary education and counseling program should be addressed in a balanced way, but to some extent, they are required to be handled separately between education and guidance and counseling.
The need for guidance and counseling in elementary schools has a fundamental need that can't be separated from the characteristics of elementary school students. Illustrates the characteristics of counseling and guidance in elementary schools are [2]:

- The main need is around the need to get affection and attention, receive recognition of the drive to advance their cognitive development, and gain recognition from friends. The developmental tasks faced by students are to organize various learning activities responsibly, to behave in order to be accepted by adults and friends and to master the basic skills of science (reading, writing, and arithmetic), developing moral awareness based on values of life (values) by forming a conscience.

- The guidance and counseling pattern that is held is that generalists mean that all educators are typically involved, although it may still be necessary for school counselors.

- Prioritized guidance and counseling components are data collection covering several key points, such as student learning abilities and family background, also include introductions to a number of areas of work relevant to students in a particular area, knowledge of how to get along well and some basic benchmarks to maintain mental health; the last two things can be presented in the form of demonstrations and games. Service can be provided by the class teacher to the parents and, of course, by the professional school counselor to the teachers in need. However, professional counseling and counseling positions are held by school counselors.

- A leading counseling and counseling function is preventive behavior so that students have a reasonable level of mental health. The healing properties will occur when there is a case deviation from the normal rate of development, which is usually closely related to the family situation. The priority of counseling and counseling is the personal-social variety, while the academic and career variety is ranked second and third. 
- The key role play is the classroom teacher, who collects data on students and inserts a lot of information materials in the learning process. Coordination of all counseling and guidance activities can be held by the principal. However, it is better to be appointed a school counselor who allegedly coordinates the implementation of guidance and counseling in primary schools. This coordinator is a generalist, in the sense of providing several procedures, either self-administered or planned for classroom teachers. For higher classes (grades 4 to 6) school counselors are no longer as coordinators but as specialized school counselors.

In order to implement the characteristics as mentioned by Winkel \& Hastuti above, it is not wrong to follow the consideration of the advice prepared by Ahman mentions a number of strategic suggestions that need to be considered in implementing guidance and counseling in primary schools as follows [3]:

- The priority aspect of providing guidance and counseling to students is learning to be an independent person.

- The student's developmental environment, both at home and in school, is physically conducive to the development of student progress, but in a quality constrained by lack of parental supervision, the lack of intensive co-operation between schools with parents and teacher orientation is still focused on the delivery of the subject matter.

- There have been elementary school activities with guidance and counseling such as in providing assistance to students with learning difficulties, providing information to parents, paying attention to the individual characteristics of the students in implementing the learning and distribution of student talents through extracurricular activities. Remembering the limited knowledge and the compact of elementary school teachers' tasks, counseling, and counseling activities are carried out incidentally, not systematically and in writing, and have not been supported by school counselor professionals and infrastructure for guidance and counseling.

- Therefore, addressing the limitations of the previous explanation points, guidance and counseling models need to be integrated into all joint educational activities in primary schools.

- Finally, long-term efforts should also be undertaken, such as providing insight and understanding of guidance and counseling in elementary school teachers on guidance and counseling as well as ongoing efforts on the carrying capacity of infrastructure for guidance and counseling in primary schools.

Based on the various perspective expressed by the experts above, it can be understood that the implementation of guidance and counseling cannot stand alone as happened in high school but demanding the role of Cooperation between classroom teachers and school counselors. Depart from the description; the researcher took research about cooperation that can be done between classroom teachers with school counselors in elementary school.

\section{METHOD}

This research was conducted by using literature review method, in conducting the research literature the researchers collected a number of studies on the implementation of guidance and counseling in primary school in 2014 until 2017 by doing the following steps.

- Collecting various researches in the form of students' final assignments and research articles published in scientific journals in the range of 2014-2017.

- The results of the collected research are then selected to obtain relevant research results to examine Cooperation between classroom teachers and school counselors in primary schools.

- Base on the results of the selection of seven research results that reflect on the review in question, to then be the basis for assessment.

- Then an attempt was made to compare and conclude by concluding the findings data

\section{RESUlT AND DISCUSSION}

Emphasized by Operational Guideline of Guidance and Counseling in Elementary school the guidance and counseling services are an integral part of education programs in schools that should be conducted by counseling teachers and counselors or counselors who have the competencies mandated in the Minister of National Education Regulation Number 27 Year 2008 regarding Academic Qualification Standards and Counselor Competencies [4]. These competencies include pedagogical competence, personality competence, social competence, and professional competence. Ideally, every elementary school has a counseling and counseling teacher or counselor. Guidance and counseling teacher or counselors work hand-in-hand with classroom teachers and subject teachers in helping students achieve optimum development. Under the condition when there are no guidance and counseling teachers, or counselors can be assigned to trained class teachers to provide counseling and guidance services.

Guidance and counseling teacher or counselors in Elementary Schools may be appointed with a range of tasks at each school or school-level cluster to help teachers develop potential and alleviate student problems. Guidance and counseling teacher or counselor at the cluster level have offices at the main school established by the District / City Education Office. In the condition of the primary school does not have sufficient space, then based in the Regional Technical Implementation Unit (UPTD) Education or the equivalent education units as described in Permendikbud Number 111 the Year 2014, Appendix point V.A 


\section{A. Corporation Between Classroom Teacher and School Counselor}

The target of service intervention is intended as work expectation shown by classroom teachers and school counselors. The intended work expectations are not only talks of professional performance but also with the ability to illustrate work skills so that students (classroom teachers) and counselee (school counselors) can receive service and realize the usefulness of the existence of classroom teachers and school counselors. In addition, intervention targets also indicate appropriate service delivery measures to accommodate the needs of service recipients. These steps include three things:

- Individuals emphasize the sincerity of individual service delivery efforts; classroom teachers are different from school counselors because individualized intervention is not a priority or a minimum, whereas for school counselors it is the priority that needs to be addressed in the form of individual counseling;

- By group, it means that the implementation of interventions emphasizes the relatively large individual, in the teaching and learning process for the classroom teacher it is important to emphasize these interventions termed classroom meetings. For implementing this technique is very diverse from group discussion to class discussion. As for group school counselors is understood in the form of group counseling with an approach that departs from the concept of group counseling;

- Classically requires classroom teachers to play an active role in showing a full learning process that is an integral part, but for school counselors, the expectation of intervention is very limited in the provision of information services and not deep.

It should be noted that the assumption of classroom teachers in primary schools can use the assumption of homeroom teachers in high school, we can use the views of [5] as presented below.

- Helping school counselors carry out the services they are responsible for.

- Providing opportunities and facilities for students, especially in the classroom for which they are responsible, to follow counseling and guidance services.

- Giving information about students in their classes to obtain counseling and guidance services from school counselors.

- Informing students who need special attention.

- Participating in special conferences [5].

\section{B. Assisting School Counselor In Conducting Guidance and Counseling}

Classroom teachers are faced with the dynamics of elementary school students in order to achieve developmental aspects consisting of three levels of objectives namely the level of recognition, accommodation, and action [6]. Facing the role of guidance and counseling in elementary school, the classroom teacher eventually doubles as a counselor, but in their work expectations, a professional school counselor may be present if their role as an expert in the counseling process or visit counselor for a counselor of some elementary schools by positioning themselves as a facilitator of students' selfdevelopment, but by positioning themselves as Visit Counselor who helps elementary school teachers overcome disruptive behaviors such as direct behavioral consultation approach [7].

Different perspective by findings of [8] on the implementation of guidance and counseling at Pacitan National Elementary School of guidance and counseling at the Natural Primary School of Pacitan is not formal yet but has been integrated which includes: tutoring, social guidance, personal guidance, and career guidance. Supporting factors for guidance and counseling at the Pacitan National Elementary School include: students are given freedom in expressing their opinions and ideas, excellent service performed by the school so that students feel comfortable, having discussions with fellow teachers and principals, all elements of the school, the presence of adequate facilities and infrastructure. Factors inhibiting the implementation of guidance and counseling in National Elementary School Alam Pacitan do not yet have a competent teacher in the field of guidance and counseling, and there are some parents who are less responsive to their children. The efforts of National Elementary School Alam Pacitan have been made to help solve the problems in the students, the way the guidance of teachers/guardians is done by creating a conducive classroom socio-emotional climate for students' learning, understanding the unique and diverse characteristics of students, marking students with suspected problems, helping students who have learning difficulties through remedial teaching programs.

Therefore, classroom teachers should be able to apply the guidance function in teaching-learning activities. Some things that need to be considered by teachers in teaching and learning process in accordance with its function as a teacher and counselor, namely: directing students to be more independent so as to be positive and fair to students by being able to give treatment to other students warmly, kindly, students' understanding is full of empathy and shows respect for the dignity of students as individuals [9].

\section{Giving Opportunity for Student to Follow Guidance and Counseling Service}

Research on the role of classroom teachers in the implementation of the field of guidance and counseling services in elementary schools taking place at National Elementary School Minomartani 6, Ngaglik, Sleman, Yogyakarta revealed that the role of classroom teachers in the implementation of the field of guidance and counseling services had been done, there are still some areas that have not been implemented optimally [10]. In addition to having the task and the role of educating, classroom teachers also have a role in implementing the field of school guidance and counseling services. Areas of counseling and guidance services conducted by teachers in schools include; in the personal, social, learning, and career fields. These service areas are 
implemented by classroom teachers based on the level of development and level of primary school students' education. In the implementation, the classroom teacher has not performed the role in career guidance to the students. This is because the level of student development is still in the preoperative stage and the level of student education is still early, which during the adjustment of education Kindergarten toward primary school education. The role of classroom teachers in the implementation of the field of guidance and counseling services can't be separated from the cooperation with the parties involved in student self-development.

Based on the report of the research from Fitri was the role of classroom teachers as teachers had been run although not maximal yet enough to provide opportunities for the running of the implementation of guidance and counseling although not yet running optimally. However, the role taken is maximum enough to be done by classroom teachers.

\section{Giving Information for Student in Class Which Need Special Attention}

Information for a student in the classroom which requires special attention is not only through limited observation but also identifying and even assisting school counselors. Research reveals the fundamental role in providing information to students who need special attention is very potential to be applied and can be seen from several aspects that are beneficial because of the class teacher naturally. (1) Understanding each student's characteristics and abilities; (2) Assisting students in solving problems; (3) Teaching social behavior and social skills; (4) Assisting students in developing the discipline of learning [11].

Disclosed on research on the role of classroom teachers in the implementation of guidance and counseling at the school inclusion elementary school Al Firdaus Surakarta that the role of classroom teachers is very important because it must understand student criteria, constraints, and classroom teacher solutions in carrying out guidance and counseling after that he can work in cooperation with school counselors [12].

Concerning the special attention concerning inclusion schools, it is interesting to place students according to psychological and physiological conditions, making the school an intensive partner inclusion. Stated by Sari about the development of children with autism in primary schools that there are three processes of identification, the design of guidance and counseling programs based on the assessment results to provide a clear focus on the ability of children to be optimized and the implementation emphasized cooperation of all parties [13].

\section{CONCLUSION}

Based on the description above, it can be taken some conclusions that are as follows : (1) Implementation of guidance and counseling in elementary schools is generally carried out by classroom teachers but assisted by visiting school counselors; (2) Although there is no specific school counselor who placed in elementary school does not mean the role of counselor does not exist, a number of studies indicate school counselors may play a behavioral consultation approach.

The partnership demands an active role of awareness of all parties with a deep understanding of the role of classroom teachers in their own counseling and counseling.

\section{REFERENCES}

[1] J. C. Dandeneau, K. O'Rourke, and C. J. Worzbyt, Elementary School Counseling: A Commitment To Caring and Community Building. USA: Brunner-Routledge, 2003.

[2] W. S. Winkel and M. M. S. Hastuti, Bimbingan dan Konseling di Institusi Pendidikan. Yogyakarta: Media Abadi, 2004.

[3] Ahman, "Model Bimbingan dan Konseling Perkembangan di Sekolah Dasar Negeri Bandung, Indonesia," Universitas Pendidikan Indonesia, 1998.

[4] Direktorat Jenderal Guru dan Tenaga Kependidikan, Panduan Operasional Penyelenggaraan Bimbingan dan Konseling Sekolah Dasar (SD). Jakarta: Kemdikbud, 2016.

[5] A. J. Nurihsan, Strategi Layanan Bimbingan dan Konseling. Bandung: Refika Aditama, 2005.

[6] Widada, "Layanan Bimbingan dan Konseling di Sekolah Dasar. Seminar Nasional Aktualisasi Bimbingan dan Konseling pada Pendidikan Dasar Menuju Siswa yang Berkarakter," in Surakarta, 2015.

[7] Widada, "Program Bimbingan dan Konseling di Sekolah Dasar," J. Pemikir. dan Pengemb. SD, vol. 1, no. 1, pp. 65-75, 2013.

[8] M. P. Dewi, "Pelaksanaan Bimbingan dan Konseling di Sekolah Dasar Alam Pacitan," Universitas Negeri Yogyakarta, 2014.

[9] Samisih, "Peran Guru Kelas dalam Menangani Kesulitan Belajar Siswa Sekolah Dasar melalui Layanan Bimbingan Belajar," J. Ilm. Mitra Swara Ganesha, vol. 1, no. 1, pp. 58-68, 2014.

[10] I. Fitri, "Peran Guru Kelas dalam Pelaksanaan Bidang Layanan Bimbingan dan Konseling di Sekolah Dasar (Studi Deskriptif di Kelas I SD Negeri Minomartani 6 Ngaglik, Sleman, Yogyakarta)," Universitas Negeri Yogyakarta, 2015.

[11] Z. A. Khabibah, "Peran Guru Kelas sebagai Pelaksana Bimbingan dan konseling bagi Siswa di SD Muhammadiyah 13 Surakarta," Universitas Muhammadiyah Surakarta, 2017.

[12] R. D. Pamuji, "Peran Guru Kelas dalam Pelaksanaan Bimbingan dan Konseling di Sekolah Inklusi SD Al Firdaus Surakarta," Universitas Muhammadiyah Surakarta, 2017.

[13] N. Sari, "Pola Pelaksanaan Bimbingan dan Konseling untuk Mengoptimalkan Kemampuan Anak Autis di Sekolah Dasar," J. Bimbing. dan Konseling Indones., vol. 1, no. 2, pp. 31-35, 2016. 